\title{
Risk Assets Management, Liquidity Management and Sustainable Performance in Nigeria Deposit Money Banks
}

\author{
Adegbie FF* and Dada OT \\ Department of Accounting, Babcock University, Ogun, Nigeria
}

\begin{abstract}
The banking industry is an active participant in the Nigeria Financial markets in building the economy through the mobilization of funds from the surplus sector to the deficit sector. Hence, the banking industry has been facing the challenge of risk asset management which culminated into some debts becoming hardcore, irrecoverable and write-off against income, added to the challenge of mismatch of funds leading to liquidity challenge in the face of risks assets becoming non-performing. The study evaluated the effect of risk asset and liquidity management on the sustainable performance of Deposit Money Banks in Nigeria. The study adopted both the ex-post factor and survey research methods. The population of this study comprised the Deposit Money Banks operating in the banking industry while the samples were three banks in addition to Central Bank of Nigeria as sample representatives. Primary data were used to obtain opinions of respondents while secondary data were used to analyze the actions taken by the managers. Both descriptive statistics and regression analysis were used for the analyses with the aid of Statistical Package of Social Sciences (SPSS). All analyses were based on level of significance 0.05., and four hypotheses were tested. The findings showed that there are strong relationships between risk asset management, liquidity management and sustainable performance in Nigeria Deposit Money Banks. With R2 of 0.738 , t-statistics of 2.526 and p-value of 0.000 , non-performing loans have significant negative impact on the assets of Deposit Money Banks in Nigeria; With R2 of 0.807 , t-statistics of 14.755 and p-value of 0.000 ,low cash deposit has a significant negative impact on the capital of Deposit Money Banks in Nigeria; With R2 of 0.725, t-statistics 11.718 and p-value 0.000 ,non-compliance with CBN's stipulated cash balance requirement has a significant negative impact on the profitability of Nigeria Deposit Money Banks; and with R2 of 0.671 , t-statistics of 10.303 and p-value of 0.000 , inadequate liquidity management has a significant negative impact on the dividend payment of Nigeria Deposit Money Banks. The study concluded that effective risk asset management and liquidity management remain the nuclear of the banking industry to maintain sustainable performance. The study recommended that the regulatory authority should enforce compliance with monetary policies; that banks should institute effective and quality risk asset and liquidity management in order to maintain financial stability and sustainability.
\end{abstract}

Keywords: Financial crisis; Investment portfolio; Liquidity management; Non-performing loan; Risk asset management; Sustainable performance

\section{Introduction}

Banks are among the most important financial institutions that contribute efficiently to the growth of any economy. They are the principal financial bedrock of the economy by sourcing funds from the surplus sector and transfer same to develop the deficit sector of the same economy. Agbada and Osuji opined that in every system, there exist major components that are important for the survival of the system which the financial system represents [1]. The banking institutions have contributed significantly to the effectiveness of the entire financial system as they offer an efficient institutional mechanism through which resources can be mobilized and directed from less essential uses to more productive investment. Banks perform financial intermediation in the general banking business which involves the mobilization of funds from excess or surplus units of the economy and giving out to deficit units as loans and advances. The performance of these functions by bank opens them to several risks; prominent among these is liquidity risk. Liquidity risk is the risk of loss to a bank resulting from its inability to meet its needs for cash. The liquidity of a commercial bank is its ability to fund all contractual obligations as they fall due. The liquidity risk in the banking industry stems from the nature of their risk assets management. This was supported by Abang when he stated that these may include lending and investment commitments and deposit withdrawals and liability maturates, in the normal course of business [2]. The introduction of banking into Nigeria economy in 1892 with the establishment of African Banking Corporation which later became
Standard Bank of Nigeria (now First Bank PLC) came with high expectation to break into the development of Nigeria economy through the provision of the needed banking services to develop the economy. Some indigenous banks were established to give financial support to Nigeria economy, but were all liquidated due to lack of technical ability to manage such institutions unlike their foreign competitors with qualified and experienced managers [3-5].

Owojori et al. opined that Banking crises in Nigeria have shown that not only do banks often take excessive risks but the risks differ across banks. Some banks engage in more risks than their capital could bear [6]. Other banks are more prudent and would be able to contain a banking crisis. As a way to stem the tide, the Central Bank of Nigeria (CBN) on July 6, 2004, introduced measures to make the entire banking system a safe, sound and stable environment that could sustain public confidence in it [4]. Okechukwu and Chigozie asserted that according to the Bank's Governor at the time, Charles Chukwuma Soludo, "it is now time to set up a structure that creates strong base relatives to the

${ }^{*}$ Corresponding author: Adegbie FF, Department of Accounting, Babcock University, Ogun, Nigeria, Tel: 08023222204; E-mail: adegbief@babcock.edu.ng

Received June 08, 2018; Accepted August 23, 2018; Published August 30, 2018

Citation: Adegbie FF, Dada OT (2018) Risk Assets Management, Liquidity Management and Sustainable Performance in Nigeria Deposit Money Banks. Int J Account Res 6: 178. doi: 10.35248/2472-114X.18.6.178

Copyright: (c) 2018 Adegbie FF, et al. This is an open-access article distributed under the terms of the Creative Commons Attribution License, which permits unrestricted use, distribution, and reproduction in any medium, provided the original author and source are credited. 
kind of economy we are operating where banks become channels to do proper intermediation based on the Obasanjo Economic Reforms on the Banking Sector, 2005" [7].

Soludo explained the Central Bank of Nigeria recapitalization and restructuring policy which brought the minimum capital base of each bank to twenty five million [8].

To minimize risk in the management of risk assets in Nigeria banks, the $\mathrm{CBN}$ issued a policy, which addresses risk asset management, corporate governance, know your customer (KYC), anti-money laundering, counter financing of terrorism, loan loss provisioning, peculiarities of different loan types and financing sectors of the economy [9]. The CBN in the new guidelines directed banks to prepare comprehensive credit policy to be approved by the Board of Directors. According to CBN (2010) and Price Waterhouse PW (2017), nonperforming loans are categorized into:

1. Substandard (overdue greater than 90days)

2. Doubtful (180-360days)

3. Lost (greater than 360days).

Non-performing specialized loans are classified into:

1. Watchful,

2. Substandard,

3. Doubtful,

4. Very doubtful

5. Lost.

The loss recognition criteria for specialized loans greater than 90 days, interest must be suspended. If it is between 90-180 days, in addition to interest suspended, the bank must make full provision for principal.

In 1988 the NDIC was set up to insure the deposits (up to a maximum of N50,000per account which have been reviewed upward to N500,000 per account in 2010) of all deposit money banks, funded by a premium of $15 / 16$ of $1 \%$ of total deposit liabilities of each as at 31 st of the previous year (NDIC, 2010).

In order to prevent a liquidity problem in the banking industry for a while, the NDIC periodically evaluates the funds management strategies of each insured bank. The process of evaluation involves a thorough appraisal of the banks administration of the capital nature of assets, and liabilities, especially qualities of loans and advances, the loans and advances are usually classified into sub-standard, doubtful and lost. The NDIC examination ensures that, adequate provision has been made for these categories of loans and advances in addition the NDIC analysis the monthly statement of bank asset and liabilities to ensure bank liquidity and also to regulate the onsite and offsite examinations [2].

Following the global financial crises which lasted from 2007-2008, and also the upshot of the banking crises which led to so many serious economic challenges all over the world, in the light of which many business organizations and investments crumpled and share-holders lost out as share prices dropped. As part of its measures to get back on track from the ruins of these economic crises, the concept of adequate liquidity management was a vital tool used by the Nigerian government via the central bank of Nigeria, to ensure the vibrancy, sustainability and stability of the banking sector. Kartik posited that liquidity is the cash available to financial institutions to support their daily obligations [10].

Quasim and Ramiz asserted that The International Accounting Standards IFRS, 2006 indicates the fact that liquidity refers to the available cash for the near future, after taking into account the financial obligations corresponding to that period [11]. Owolabi and Obida defined liquidity as the degree of convertibility to cash or the ease with which any assets can be converted to cash (sold at a fair market price) [12].

According to the circular issued to all deposit money banks in Nigeria (CBN) on $29^{\text {th }}$ January 2009 as regards its liquidity composition, includes: Vault cash, Balance held with CBN, Net balances held with banks within Nigeria, Nigerian Treasury bills, CBN Registered certificates, Net interbank placement with other banks, Net money at call with other banks, Net placement with discount houses, Total certificate of deposit, FGN Bonds and Stabilization securities. Liquidity management therefore involves the strategic supply or withdrawal from the market or circulation the amount of liquidity consistent with a desired level of short-term reserve money without distorting the profit making ability and operations of the bank. It relies on the daily assessment of the liquidity conditions in the banking system, so as to determine its liquidity needs and thus the volume of liquidity to allot or withdraw from the market [13]. The liquidity needs of the banking system are usually defined by the sum of reserve requirement, imposed on the banks by a monetary authority (CBN, 2012). Under the new dispensation, sustaining monetary stability will be achieved through greater coordination between the $\mathrm{CBN}$ and the federal ministry of finance, in order to limit government borrowing from the bank to the level stipulated by law [14].

Two criterions are involved in liquidity management within a financial institution. First, the institution must be sure that appropriate low cost funding is available at short notice. This may involve holding a portfolio of assets that can easily be sold, holding significant volumes of stable liabilities, or maintaining credit lines with other financial institutions. Second, liquidity management must meet profitability requirements. Financial stability issues lies precisely at this liquidity/ profitability nexus: banks must manage liquidity stocks and flows in the most profitable manner that does not jeopardize financial stability [15]. The recent global financial crisis and its impact on the Nigerian banking sector has shown that CBN's daily forecasts of banking sector liquidity is not sufficient in assessing the liquidity requirement of the sector as several banks remain relatively fragile and incapable of withstanding periodic liquidity shocks [16].

\section{Nigeria Economy Outlook}

Lipsey as cited by Ajibola asserted that "An economy refers to any specified collection of interrelated set of markets and non-marketed productive activities that in essence" Nigerian economy refers to all such economic activities taking place in the geographical domain of Nigeria (Domestic economy) or all such economic activities of Nigeria wherever they perform them in the world (National Economy). Ajibola asserted that industrialization process seems to be the main hope of developing connection and against the backdrop, current economic planning and policy instruments are directed at the development of the key productive sectors, particularly manufacturing and commerce from the promotion of an increasing pace of industrialization in Nigeria [17]. An economy can be driven by structural transformation with integrated approach to make all the sectors of such economy to be productive. African Economic Outlook-AEO explained that Nigeria 
economic growth has been sluggish since the end of 2015, which led the government of the nation to adopt expansionary 2016 budget with the objective of stimulating the economy [18]. The global fall in the price of crude oil, fall in growth from $6.2 \%$ in 2014 to $3.0 \%$ in 2015 , increase in inflation from $7.8 \%$ to an estimated $9.0 \%$ have negative effect on the economy. They explained further that the reason for this position could be attributed to a slowdown in economic activity which has been due to inadequate supply of foreign exchange and foreign exchange restrictions. Asogwa et al. analyzed the economic situation of Nigeria which covers the following: that in Nigeria economy went into recession in 2016 because of adverse economic shocks, economic policies instability, and challenges in security [19]. Central Bank of Nigeria responded by reviewing the monetary, fiscal and exchange rate policies in order to sanitize the economy so as to take it out of recession. The apex bank introduced monetary policy which increased rate to $14 \%$ in 2016 from $11 \%$ in 2015 , so as to attract capital inflow and control upward ticking inflation. CBN reduced cash reserve requirement in order for banks to extend credit to classified sectors at a single digit interest rate. This action taken resulted in the broad money supply which along with the cost push factors resulting into fuel, power and those foreign exchange shortages to the upward trend in the inflation to $15.7 \%$ in 2016 from $9.1 \%$ in 2015 . The government pursued expansionary economy by focusing attention on capital expenditure. (The foreign reserves of the nation reduced after the implementation of all the actions. Reduction from $\$ 28$ billion in 2016 to $\$ 25$ billion in 2015) Asogwa opined that there was a slow economic recovery in the year 2017. He posited that the government gave priority to Nigeria Industrial Revolution Plan (NIRP) which identified mining and quarrying, which contributed $7.1 \%$ to overall GDP in 2016. The economic position of the nation showed that manufacturing sector experienced a decline of $2.6 \%$ in 2016 because of increase in the costs of business operations, which resulted mainly from foreign exchange restrictions that 272 firms shut down in 2016 which reduced industrial capacity utilization from $51.4 \%$ in 2015 to $35.4 \%$ in 2016 . This is a remarkable negative impact of the real sector on the economic growth and development of Nigeria. FSDH Research explained that the foreign exchange shortage and the pressure on the Nigerian economy from the external sector have changed the consumption and the production patterns in Nigeria [19,20]. With these, Nigeria needs to look inward and build comparative advantage that will create employment opportunity, industrialize the economy and provide the platform to earn the needed foreign exchange. They submitted that Nigerian economy needs to be competitive before it can create the wealth that is required for the growing population, which will in turn ensure an inclusive and sustainable growth.

\section{Statement of the Problem}

The banking sector which has been regarded as the financial bedrock of the nation invests in deficit sector of the economy through which some level of risks and uncertainties are accommodated. One major risk is non-payment of loan and advances by borrowers which has negative effect on the operations of the banking institutions. These results into the erosion of the asset base of the banks affected. Alford as cited by Samuel stated that "following the special examination and during the period from December 2008 to December 2009, Nigerian banks wrote off loans equivalent to $66 \%$ of their total capital, most of these write offs occurred in the eight banks receiving loans from the CBN [13]. The main objective of banks is to maximize profit, and to achieve this goal they endeavor to mobilize high level of deposit from the general public. With the competitive nature of the money market, they try as much as possible to attract new customer and retain their existing customers through improved marketing and provision of efficient services. There has been the challenge of attracting sufficient deposits to meet their service demands. Excessive charges, setting minimum balances on accounts, unfriendly environment and inexperience bank staff on the need to total quality management are the issues that require management attention of banks. Non-compliance with various Central Bank monetary policies regarding cash reserve requirements to meet their daily operations, poor liquidity management of asset and liquidity mismatch are major changes in the banking institutions. Most Deposit Money Banks lack the sound process of identifying, measuring, monitoring and controlling liquidity risk. They lack a robust framework for comprehensively projecting cash flows arising from assets, liabilities over an appropriate set time horizons. These have led to forced sales of their assets at unfavorable market conditions and losses to meet customers short run obligations in order to maintain the confidence of the customers. Banks are forced into liquidating their businesses if they can no longer continue in business. According to CBN and Onoh, explained that 22 banks were liquidated before independence, 3 banks in 1992, 4 banks in 1994, 26 banks in 1998 and 14 banks in 2005 were liquidated respectively. All these liquidations were compelled due to very bad risk assets and liquidity which affected the sustainability of the affected banks [4,5]. The CBN merged 91 banks operating in 2004 to 25 banks in 2005 and further down to 21 banks due to the same challenges.

\section{Objectives of the Study}

The following objectives were set for the research:

1. To evaluate the impact of non-performing loans on the asset growth of Nigeria Deposit Money Banks with a view to ensuring sustainable performance.

2. To examine the impact of low level of cash deposit on the capital of Nigeria Deposit Money Banks with a view to ensuring efficiency.

3. To examine the impact of non-compliance with CBN monetary policy on cash reserve requirement with a view to ensuring compliance.

4. To investigate the impact of inadequate liquidity management on dividend payment with a view to ensuring adequate liquidity management.

\section{Research Hypotheses}

The following hypotheses were tested for the research work.

$\mathbf{H}_{0} \mathbf{1}$ : Non-performing loans do have a significant negative impact on the assets growth of Nigeria Deposit Money Banks.

$\mathbf{H}_{0}$ 2: Low cash deposit level does not have a significant negative impact on the capital of Nigeria Deposit Money Banks.

H 3: Non-compliance with Central Bank of Nigeria stipulated cash reserve requirement does not have a negative significant impact on the profitability of Nigeria Deposit Money Banks.

$\mathbf{H}_{0}$ 4: Inadequate liquidity management does not have a significant negative impact on the dividend payment of Nigeria Deposit Money Banks.

\section{Operationalization of Variables and Model Specification}

$\mathrm{Y}=\mathrm{f}(\mathrm{X})$

$\mathrm{Y}=$ Sustainable Performance (SP)

$\mathrm{X}=$ Risk Assets and Liquidity Management 
$\mathrm{Y}=\mathrm{y}_{1}, \mathrm{y}_{2}, \mathrm{y}_{3}, \mathrm{y}_{4}$

$\mathrm{X}=\mathrm{x}_{1}, \mathrm{x}_{2}, \mathrm{x}_{3}, \mathrm{x}_{4}$

\section{Sub-variables for $Y$ are}

$\mathrm{y}_{1=}$ Asset Growth (AST)

$\mathrm{y}_{2=}$ Capital (CAP)

$\mathrm{y}_{3=}$ Profitability (PROF)

$\mathrm{y}_{4=}$ Dividend (DVD).

\section{Sub-variable for $\mathrm{X}$ are}

$\mathrm{x}_{1}=$ Non-Performing loans (NPL)

$\mathrm{X}_{2=}$ Cash Deposit

$\mathrm{x}_{3=}$ Cash Reserve Requirement(Cash Balance) (CRR)

$\mathrm{x}_{4=}$ Inadequate Liquidity Management (ILM).

\section{Functional relationship}

$\begin{array}{ll}\text { ASTG }=f(N P L) & (\text { Model } 1) \\ \mathrm{CAP}=f(\mathrm{CD}) & (\text { Model 2) } \\ \mathrm{PROF}=\mathrm{f}(\mathrm{CRR}) & (\text { Model } 3) \\ \mathrm{DVD}=\mathrm{f}(\mathrm{ILM}) & (\text { Model } 4) .\end{array}$

\section{Model specification}

Models 1 to 3 were tested using secondary data while model 4 was tested using primary data.

$$
\begin{aligned}
& \text { ASTG }=\beta_{0+} \beta_{1} \text { NPL } \\
& \text { CAP }=\beta_{0}+\beta_{1} \text { LCD } \\
& \text { PROF }=\beta_{0+} \beta_{1} \text { CRR } \\
& \text { DVD }=\beta_{0}+\beta_{1} \text { ILM }
\end{aligned}
$$

\section{Conceptual Model}

\section{Concept of liquidity}

According to the Basel committee, Liquidity is the ability of a bank to fund increases in assets and meet obligations as they come due, without incurring unacceptable losses [21]. The fundamental role of banks in the maturity transformation of short-term deposits into long-term loans makes banks inherently vulnerable to liquidity risk, both of an institution-specific nature and that which affects markets as a whole. Virtually every financial transaction or commitment has implications for a bank's liquidity (Figure 1). Effective liquidity risk management helps ensure a bank's ability to meet cash flow obligations, which are uncertain as they are affected by external events and other agent's behavior. Liquidity risk management is of paramount importance because a liquidity shortfall at a single institution can have system-wide repercussions. Financial market developments in the past decade have increased the complexity of liquidity risk and its management. Patricia and Izuchukwu stated that liquidity is the ability of bank to fund increases in assets and meet obligations as they come due, without incurring unacceptable losses [22]. Liquidity risk arises from the fundamental role of banks in the maturity transformation of short-term deposits into long-term loans. It includes two types of risk: funding liquidity risk and market liquidity risk. Funding liquidity risk is the risk that the bank will not be able to meet efficiently both expected

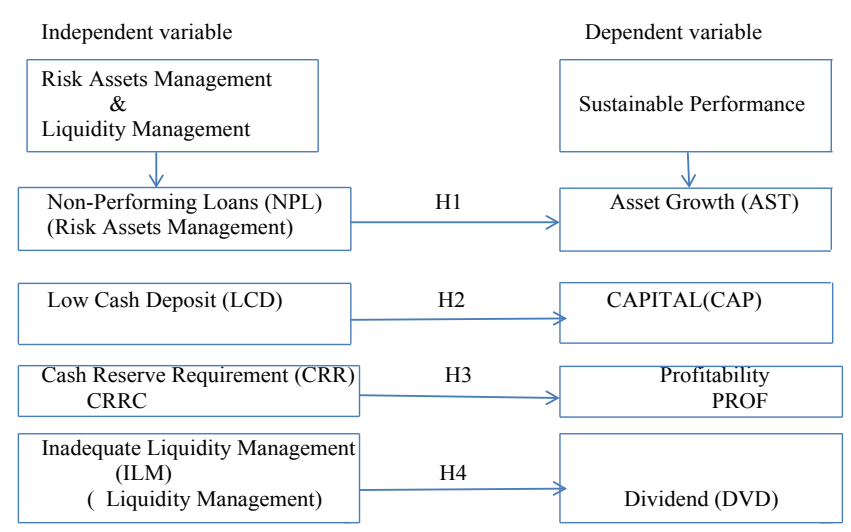

Figure 1: Conceptual model.

and unexpected current and future cash flow and collateral needs without affecting either daily operations or the financial condition of the firm. Market liquidity risk is the risk that a bank cannot easily offset or eliminate a position at the market price because of inadequate market depth or market disruption. High liquidity means there is a lot of capital because interest rates are low, and so capital is easily available. Why are interest rates so important in controlling liquidity? Because this rates really dictates how expensive it is to borrow. Low interest rates mean credit is cheap, so businesses and investors are more likely to borrow. The return on investment only has to be higher than interest rate, so more investments look good in this way, high liquidity spurs economic growth [14]. Regina opined that bank performance depends the on the efficient utilization of its resources, with the consideration of putting risks into appraisal to minimized the operating risks [23]. That the financial institutions should operate minimal risks that will not significantly affect performance. She further reiterated that professional cost control, creativity in ideas generation, and compliance with rules and regulations will affect managers' effectiveness.

Liquidity risk: According to Njogo Liquidity Risk is the ability of a bank to fund increases in assets and meet obligation as they come due, without incurring unacceptable losses [24]. The fundamental role of banks in the maturity transformation of short-term deposit into long-term loans makes banks inherently vulnerable to liquidity risk. Effective liquidity risk management helps ensure cash flow obligations, which are uncertain as they affected by external events and other agents behavior. Fundamental Principle for the Management and Supervision of Liquidity Risk in the banks are: A bank is responsible for the sound management of liquidity risk; A bank should clearly articulate a liquidity risk tolerance that is appropriate for its business strategy and its role in the financial system; Senior management should develop a strategy, policies and practices to manage liquidity risk in accordance with the risk tolerance and to ensure that the bank maintains sufficient liquidity; A bank should incorporate liquidity costs, benefits and risks in the internal pricing, performance measurement and new product approval process for all significant business activities, thereby aligning the risk-taking incentives of individual business lines with the liquidity risk exposures their activities create for the bank as a whole; A bank should have a sound process for identifying, measuring, monitoring and controlling liquidity risk. This process should include a robust framework for comprehensively projecting cash flows arising from assets, liabilities and off-balance sheet items over an appropriate set of time horizons; A bank should actively monitor and control liquidity risk exposures and funding needs within and across legal entities, 
business lines and currencies, taking into account legal, regulatory and operational limitations to the transferability of liquidity; A bank should establish a funding strategy that provides effective diversification in the sources and tenor of funding; A bank should actively manage its intraday liquidity positions and risks to meet payment and settlement obligations on a timely basis under both normal and stressed conditions and thus contribute to the smooth functioning of payment and settlement systems; A bank should actively manage its collateral positions, differentiating between encumbered and unencumbered assets. A bank should monitor the legal entity and physical location where collateral is held and how it may be mobilized in a timely manner; A bank should have a formal contingency funding plan (CFP) that clearly sets out the strategies for addressing liquidity shortfalls in emergency situations; A bank should maintain a cushion of unencumbered, high quality liquid assets to be held as insurance against a range of liquidity stress scenarios, including those that involve the loss or impairment of unsecured and typically available secured funding sources; There should be no legal, regulatory or operational impediment to using these assets to obtain funding; and Supervisors should regularly perform a comprehensive assessment of a bank's overall liquidity risk management framework and liquidity position to determine whether they deliver an adequate level of resilience to liquidity stress given the bank's role in the financial system.

\section{Theoretical review}

The following theories were review to have underpinning principles and ideas for the research work.

Anticipated income theory: This posits that banks liquidity position is very important, and that proper structure of the loan that will connect the future of the business repayment to the purpose of disbursing the money lent. Nzotta as cited in Sunny reiterated that the creditworthiness of the borrower is consideration for ability to make future repayment. Nwankwo as cited in Sunny was of the opinion that the theory opens the fact that every loan granted should in future, liquidate it [25]. The theory is hinged on the ability of the borrower to pay back the loan with interest as at when due, putting into consideration critically the earning potentials of such borrower. It is assumed that banks will always remain liquid as loans are been paid back as at when due, and the assets with maintain growth and performing status. The theory holds that banks liquidity and quality of earning assets can be influenced by the maturity pattern of the loans and investment portfolios, short-term business and customer installment loans which would have more liquidity than those secured by real estate [26].

Shiftability theory: This theory says that a bank is guaranteed future liquidity if the facility is secured with assets that can be sold in the open market. Sunny explained that a bank is secured and guaranteed liquidity if the asset can be sold at market price. Daddy as cited in Sunny was of the opinion that any asset that possesses shiftability, marketability, and transferability will guarantee liquidity. Sunny was of the opinion that this point of view contends that liability management must seek to answer the following questions: How do we obtain funds from depositors?; How do we obtain funds from other creditors?;-What is the appropriate mix of the funds of any bank?; Management examines the activities involved in supplementing the liquidity needs of the bank through the use of borrowed funds. The forces of the liquidity management theory are on the liability side of the bank's balance sheet [25].

Liquidity asset theory: This theory focuses on the asset side of the balance sheet and argues that banks must hold large amount of liquid assets against possible demand or payment cushion of readily marketable short-term liquid asset against unforeseen circumstances [2]. However this theory might put banks in a position, in which it has excess liquid asset which might impair return on asset as cash lies idle in the vault in anticipation of unforeseen circumstances. Ngwu opined that this approach is very expensive in a current world of dynamic money market. This theory gives focus to the research work, as it emphasis the fact that the banking sector can be caught unawares by unforeseen circumstances, so it stresses that banks should hold large amount of liquid asset which are readily marketable in short-term so that they can always respond accordingly and reasonably to unforeseen circumstances [26]. This gives a pointer to adequate liquidity management; however a point banks should consider is not to keep cash in excess of what is stipulated by the CBN in their vaults, which would have been invested in form of loans and advances as it impairs the profit making ability of commercial banks. Thus this theory gives a focus in term of adequate planning and structuring of the banks liquidity to ensure that the banks are not caught unawares by unforeseen events in the course of fulfilling their day to day obligations to their customers. All these theories are fundamental for risk and liquidity management for any bank to maintain sustainable performance growth in Nigeria economy.

\section{Empirical review}

Non-performing loans and bank's asset: Regina asserted that the quality of assets to be taken as security for a loan should be a function of the type and risk of loans granted to the borrower [23]. That the higher the ratio of assets to the total exposure of the borrower to the bank, the better for the bank. That the bank must ensure the future repayment of the loan from the sources of repayment. However, in the event of risks of repayment, the quality of assets will come into decision. That loans and advances could create instability for the bank and have effect on their profitability if they become irrecoverable. The irrecoverable state of the loans and advances can result into poor purchasing power and other exposure risk of illiquidity and insolvency. She however stated that litigation on loan defaulters can expose banks to the public and have negative effect on their image. This position was supported by Adegbie et al. when they posited that banks should consider cash inflows from the borrower and the ability of the bank to convert the mortgaged assets to cash in the position of the borrower's inability to repay [27]. That the only position that can make a bank to have sustainable business performance is to be able to get repayments of loans and advances from borrowers or for closed the mortgaged assets at reasonable realizable value.

Goldstoin and Turne as cited in Somoye noted that Non-performing Loans (NPLs) have become contemporary issues in credit management and undoubtedly the new frontier in finance. The accumulation of Non-performing Loans (NPLs) is generally attributable to a number of factors, including economic down turns and macroeconomic volatility, terms of trade deterioration, high interest rates, excessive reliance on overly high-priced inter-bank borrowings, insider lending and moral hazard [28]. Adegbie et al. also noted that mismatching of assets and liabilities in banks' lending decision has caused financial distress and liquidation of banking institutions in Nigeria going by financial history from pre-independence to date. Enyi opined that the non-compliance of banks with lending policies has been of the major causes of financial distress and liquidity challenge in the banking industry, since most of the banks are not adhering to CBN liquidity and lending ratios [29]. 
Cash deposit and banks capital: Mishkin and Seletis as cited in Ekankumo and Koroye explained that banks are profit seeking oriented organizations whose ability to retain deposits from customers, give loans to users of funds make them to be involved in capital creation, which profits to the banks, and revenue to the nation on the long run [30]. This is to say that the grow of deposits, good management of risk assets will have chain effect on profit realization, distribution of profit to the nation through taxation, retention of profit for the growth of capital of the banks. This in effect will have positive effect on the sustainable performance of the banking institutions. The principal assets of a bank as posited by them are the securities they buy (which pay interest and dividends) and the loans they make to individual household to buy properties and to business organizations for investments. Thus banks have two major portfolios which are loans and investment portfolios. Regina reveals that a merger is associated with improvement in overall performance and that the overall performance of or the strength of a bank depends primarily on the sources of capital funds available to it, the quality of corporate governance, and the growth prospects [23]. It also depends on liability management and the investment portfolio management of such funds. Regina posited further that capital adequacy is the level of unimpaired capital resources needed by a bank to sustain its operations. Capital adequacy is measured using two principal ratios, which are ratio of classified loans and advances to shareholders fund and ratio of capital to risk-weighted assets. She concluded that the first ratio defines capital adequacy from the perspective of capital cover for a bank's non-performing loans, while the second defines capital adequacy from the standpoint of risky assets (assets whose reliability is doubtful) and that adequate capital cover enables banks to hedge against risks even in the event of liquidation. According to Soludo, the Nigerian banking system was fragile and marginal because of low capitalization, which made them lea able to finance the economy, and more prone to unethical and unprofessional practices [8]. That Nigerian banking system was characterized by poor loan quality of up to 21 percent of shareholders' funds compared with 1 to $2 \%$ in Europe and America; overtrading, abandoning the true function of banking to focus on quick profit ventures such as trading in forex and tilting their funding support in favor of import-export trade instead of financing manufacturing; reliance on unstable public sector funds for their deposit base. Uchendu as explained in Lawrence corroborated the fact that the reforms in the banking sector preceded against the backdrop of banking crisis due to highly undercapitalization deposit taking banks; weakness in the regulatory and supervisory framework; weak management practices and the tolerance of deficiencies in the corporate governance behavior of banks [31].

Banks liquidity and dividend policy: Ibrahim was of the opinion that dividend policy will have effect on dividend paid to shareholders and inappropriate funds for reserve normally set aside for growth [32]. He further reiterated that section 370 (1) of CAMA (2004) empowers the directors to recommend dividends payable in annual general meeting, which according to sub-section 3 may increase or decrease in value. That dividend can only be paid out of the annual profit. Hashim et al. found out that there exists a positive relation between the liquidity and profitability explaining that firms earning stable cash flow (high liquidity) are in position to pay higher dividends as compared to firms facing unstable earning [33]. They found positive relationship between liquidity and dividend pay-out policy suggesting that due to shortage of cash, poor liquidity results in less generous dividend payout policies. They further stated that firms having improved financial position initiates dividend increments while companies facing financial problems triggered by decreasing profitability and low liquidity levels are forced to cut dividends. They concluded that dividend reducing firms face liquidity problems, and that three exist a negative relationship between liquidity and higher return on equity stimulates the firm need to retain more to reinvest or lower dividend.

Compliance with regulatory laws on requirements and profitability: Douglas asserted that capital requirements for banks and the rules governing the resolution of insolvent banks will have effect on liquidity requirements [34]. The level of bank capitalization will influence the liquidity position of such banks, and have effect on public confidence on the banks. That low capitalization will have negative effect on their liquidity and level of transactions. Unaeze explained that there are some extra measures adopted by Central Bank of Nigeria to foster safe sound banking culture while also serving as tools to correct unusual and very serious anomalies detected by the apex bank [35]. These are mandatory for all banks to comply in order to retain confidence of the stakeholders and maintain sustainable performance and growth of the banks. The recapitalization policy of 2004 mandated all banks operating in Nigeria to increase their capital base from five billion naira to twenty five billion which lead to the merger and acquisition of ninety one banks to twenty five banks. Fourteen banks that could not comply went into extinction. In line with Banks and Other Financial Act of 2004, the CBN abolished universal banking and re-categorized banks into three groups according to location to be covered in their operations and volume of their capital base. The first group is regional banking with a capital of N10billion and must cover a minimum of six states and maximum of 12 states within two geographical zones in Nigeria as well as Federal Capital Territory. The second is national banking with a capital base of N25 billion, with a coverage of all the states of the federation, and third is group of international banking that requires a capital of N50billion and the right to cover the whole country of Nigeria and any other country of their country of their choice outside Nigeria subject to the approval of Central bank of Nigeria [36-39].

\section{Methodology}

The study employed ex-post facto and survey designs respectively. Survey research design was used to obtain opinions from sampled population. Ex post facto research design was adopted to obtain secondary data from the sampled population to effectively understand the impact of risk asset management and liquidity management on the sustainable performance of deposit money banks. The population of study was twenty [20] deposit money banks in Nigeria as at 2014 when further merger of banks reduced the twenty five [25] deposit money banks. Three deposit money banks which are more than $10 \%$ of the population were sampled. The three banks are United Bank for Africa which represented the first generation banks, Zenith Bank PLC, which represented the middle generation of structural adjustment programme (SAP) banks, while Skye bank represented the new generation banks. The banks have total asset base of N3trillion with 350 branches spread across Nigeria and presence in United Kingdom and some African countries. The sampling technique is proportionate sampling method which allowed minimum of $10 \%$ of the population as sample. For the primary data, 60 copies of the questionnaire with five like rt scale were administered to the staff of the three banks with specialty in risk asset management. 54 copies of the questionnaire were retrieved which represented $90 \%$ of the administered copies of the questionnaire. The total data used were $54 \mathrm{x} 5$ scales $\mathrm{x} 3$ banks $=810$. The secondary data collected were the available data from 2010 to 2014 which was the period 20 deposit money banks operated in the economy. Eight variables were used for the study for a period of 5years for 3banks which total 120 
Citation: Adegbie FF, Dada OT (2018) Risk Assets Management, Liquidity Management and Sustainable Performance in Nigeria Deposit Money Banks. Int J Account Res 6: 178. doi: 10.35248/2472-114X.18.6.178

Page 7 of 10

data, i.e. 8 variables ${ }^{\star} 5$ years ${ }^{\star} 3$ banks. Single linear regression was used to analyze the data. The results obtained were used to generalize since all the banks operate under the same business characteristics. The secondary data were used to test hypotheses one to three, while the questionnaire was used to test hypothesis four (Tables 1-3).

\section{Research Findings}

\section{Test of hypotheses-secondary data}

The findings are analyzed below:

$\mathbf{H}_{0} \mathbf{1}$ : Non-performing loans do have a significant negative impact on the assets growth of Nigeria Deposit Money Banks (Tables 4-6).

Degree of freedom $(\mathrm{Df})=\mathrm{n}-1$ 4-1=3

$\mathrm{ASTG}=\beta 0+\beta 1 \mathrm{NPL}$

(Model 1)

ASTG=1466483-23809.

From Table 3, the coefficient of non-performing loans is -23809 , which is negative and shows that there is a negative relationship between non-performing loans and asset growth of the banks. This means that non-performing loans have negative impact on the assets growth of the deposit money banks in Nigeria. Table 1 show $\mathrm{R}^{2}$ which is the explanatory power of the variable is 0.171 or $71.7 \%$, which indicates that $71.7 \%$ of the variations in asset growth are due to non-performing loans. The remaining $28.3 \%$ difference is explained by the variation in the dependent variable. At level of significance 0.05 and degree of freedom 53, $\mathrm{t}$-calculated is -2.754 less than 2.132 tabulated and $\mathrm{p}$-value of 0.71 which is more than 0.05 Level of Significance (LoS). With this result, we accept the null hypothesis which says that non-performing do have significant negative impact on the asset of the deposit money banks in Nigeria (Table 2).

$\mathbf{H}_{0}$ 2: Low cash deposit level does not have a significant negative impact on the capital of deposit money banks in Nigeria.

$\mathrm{CAP}=\beta_{0}+\beta_{1} \mathrm{LCD}$

(Model 2)

\section{$\mathrm{CAP}=139769+980$}

From Table 6, the coefficient Deposit is 0.980 which is showing a positive relationship between cash deposit and capital in money deposit banks in Nigeria. This means that cash deposit have a significant impact on the capital of deposit money banks. Table 4 shows the $\mathrm{R}^{2}$ is .994 or $99.4 \%$ which is the overall coefficient of determination or explanatory power of the variable. This indicates that $99.4 \%$ of the variations in capital are due to cash deposit. The remaining $0.6 \%$ of changes however, are explained by variables nor considered in this work but can cause variation in the dependent variable (capital) (Tables 6-9).

\begin{tabular}{|c|c|c|c|c|}
\hline Model & $\mathbf{R}$ & $\mathbf{R}$ Square & Adjusted R Square & Std. Error of the Estimate \\
\hline 1 & $0.846^{\mathrm{a}}$ & 0.717 & 0.622 & 130221.3878 \\
\hline aPredictors: (Constant), NPL@Banks.
\end{tabular}

Table 1: Model Summary

\begin{tabular}{|c|c|c|c|c|c|}
\hline Model & Sum of Squares & df & Mean Square & $\mathbf{F}$ & Sig \\
\hline Regression & 128579855172.498 & 1 & 128579855172.498 & \multirow[t]{3}{*}{7.582} & \multirow[t]{3}{*}{$0.071^{b}$} \\
\hline Residual & 50872829524.702 & 3 & 16957609841.567 & & \\
\hline Total & 179452684697.2 & 4 & & & \\
\hline
\end{tabular}

Table 2: Anova ${ }^{a}$

\begin{tabular}{|c|c|c|c|c|}
\hline \multirow{2}{*}{ Model } & Unstandardized Coefficients & Standardized Coefficients & Sign \\
\cline { 2 - 4 } & B & Std. Error & Beta \\
\hline (Constant) & 1466483 & 181758.7 & -0.846 & 8.068 \\
\hline NPL@Banks & -23.809 & 8.647 & 0.004 & -2.754 \\
\hline aDependent Variable: Asset@Banks. & & 0.071 & \\
\hline
\end{tabular}

Table 3: Coefficients

\begin{tabular}{|c|c|c|c|c|}
\hline Model & $\mathbf{R}$ & R Square & Adjusted R Square & Std. Error of the Estimate \\
\hline 1 & $0.997^{\mathrm{a}}$ & 0.994 & 0.992 & 13505.40273 \\
\hline aPredictors: (Constant), Deposit@SKYE. & & & \\
\hline
\end{tabular}

Table 4: Model Summary.

\begin{tabular}{|c|c|c|c|}
\hline Model & Sum of Squares & df & Mean Square \\
\hline Regression & 87727884966 & 1 & $8.77 \mathrm{E}+10$ \\
\hline Residual & 547187708.3 & 3 & $1.82 \mathrm{E}+08$ \\
\hline Total & 88272072674 & 4 & 480.959 \\
\hline aDependent Variable: Capital@SKYE; b. Predictors: (Constant), Deposit@SKYE & \\
\hline
\end{tabular}

Table 5: Anova ${ }^{a}$

\begin{tabular}{|c|c|c|c|c|}
\hline \multirow{2}{*}{ Model } & \multicolumn{2}{|c|}{ Unstandardized Coefficients } & Standardized Coefficients & Sign \\
\cline { 2 - 5 } & B & Std. Error & Beta \\
\hline (Constant) & 139769.2 & 32197.53 & 0.997 & 4.341 \\
\hline Deposit@Skye & 0.98 & 0.045 & 0.023 & 21.93 \\
\hline aDependent Variable: Capital@SKYE. & & & 0 \\
\hline
\end{tabular}

Table 6: Coefficients ${ }^{a}$ 
Citation: Adegbie FF, Dada OT (2018) Risk Assets Management, Liquidity Management and Sustainable Performance in Nigeria Deposit Money Banks. Int J Account Res 6: 178. doi: 10.35248/2472-114X.18.6.178

Page 8 of 10

\begin{tabular}{|c|c|c|c|c|c|c|}
\hline Model & $\mathbf{R}$ & R Square & \multicolumn{2}{|c|}{ Adjusted R Square } & \multicolumn{2}{|c|}{ Std. Error of the Estimate } \\
\hline 1 & $0.632^{\mathrm{a}}$ & 0.4 & \multicolumn{2}{|c|}{0.199} & \multicolumn{2}{|c|}{3267.82} \\
\hline \multicolumn{7}{|c|}{ aPredictors: (Constant), Bank balance@Banks. } \\
\hline \multicolumn{7}{|c|}{ Table 7: Model Summary. } \\
\hline \multicolumn{2}{|l|}{ Model } & Sum of Squares & df & Mean Square & $\mathbf{F}$ & Sig \\
\hline \multicolumn{2}{|l|}{ Regression } & 21313536 & 1 & 21313536.4 & \multirow[t]{3}{*}{1.996} & \multirow[t]{3}{*}{$0.253^{\mathrm{b}}$} \\
\hline \multicolumn{2}{|l|}{ Residual } & 32035938 & 3 & \multirow[t]{2}{*}{10678646.14} & & \\
\hline \multicolumn{2}{|l|}{ Total } & 53349475 & 4 & & & \\
\hline
\end{tabular}

Table 8: Anova

\begin{tabular}{|c|c|c|c|c|}
\hline \multirow{2}{*}{ Model } & Unstandardized Coefficients & Standardized Coefficients & Sign \\
\cline { 2 - 5 } & B & Std. Error & Beta & 0.632 \\
\hline (Constant) & 5630.585 & 3827.198 & 1.471 & 1.413 \\
\hline Bank balance @Skye & 0.053 & 0.038 & 0.238 & \\
\hline aDependent Variable: PAT@Banks. & & \\
\hline
\end{tabular}

Table 9: Coefficients ${ }^{a}$.

\begin{tabular}{|c|c|c|c|c|}
\hline Model & $\mathbf{R}$ & R Square & Adjusted R Square & Std. Error of the Estimate \\
\hline 1 & $0.819^{a}$ & 0.671 & 0.665 & 0.34695 \\
\hline aPredictors: (Constant), Bank balance@Banks. & \\
\hline
\end{tabular}

\section{Table 10: Model Summary.}

\begin{tabular}{|c|c|c|c|c|}
\hline Model & Sum of Squares & df & Mean Square \\
\hline Regression & 12.777 & 1 & 12.777 \\
\hline Residual & 6.26 & 52 & 0.12 \\
\hline Total & 19.037 & 53 & 06.146 \\
\hline aDependent Variable: Dividend; b. Predictors: (Constant), inadequate liquidity management & \\
\hline
\end{tabular}

Table 11: Anova ${ }^{a}$.

At the level of significance 0.05 and degree of freedom 3, the level of significance is 0.000 which is less than 0.05 .The t-statistics is 21.931 which is greater than 2.132 tabulated. We therefore reject the null hypothesis and accept the alternate which shows that Low cash deposit level have a significant negative impact on the capital of deposit money banks in Nigeria (Table 5).

$\mathbf{H}_{0}$ 3: Non-compliance with Central Bank of Nigeria stipulated cash reserve requirement does not have a negative significant impact on the profitability of Nigeria Deposit Money Banks.

$$
\mathrm{PROF}=\beta_{0+} \beta_{1} \text { CRRC }
$$

(Model 3)

$\mathrm{PROF}=5631+053$

From Table 9, the coefficient of Cash Reserve Requirement on Bank balance is 0.053 which is shows a positive relationship between Cash reserve requirement bank balance and profitability of deposit money banks in Nigeria. This is an indication that cash reserve requirement bank balance has a significant impact on the profitability of deposit money banks in Nigeria. From Table 7, the $\mathrm{R}^{2}$ which is overall coefficient of determination or the explanatory power of the variable is .400 or $40 \%$.This indicates that $40 \%$ of the variation in profitability are due to compliance. The remaining $60 \%$ of changes however, are explained by variables not considered in this work, but can cause variation in the dependent variable (profitability). At the level of significance of 0.05 and degree of freedom 3, the t-statistic is 1.413 which is lower than the tabulated of 2.132 , and the p-value of the t-statistics is 0.253 which greater than 0.05 . We therefore accept the null hypothesis which means compliance with cash requirements does not have a significant negative impact on the profitability of deposit money banks in Nigeria (Table $8-12)$.

\section{Test of hypothesis-primary data}

$\mathbf{H}_{\mathbf{0}}$ 4: Inadequate liquidity management does not have a significant negative impact on the dividend payment of Nigeria Deposit Money Banks.

$$
-\mathrm{DVD}=\beta_{0}+\beta_{1} \text { ILM }
$$

Cronbach Alpha reliability rate $=0.75$

$\mathrm{DVD}=1.077+.775$.

From Table 12, the coefficient of inadequate liquidity management is 0.775 , which shows that there is a positive relationship between inadequate liquidity management and dividend. This means that inadequate liquidity management has a significant negative impact on the dividend of deposit money banks in Nigeria. The $\mathrm{R}^{2}$ which is the overall coefficient of determination or the explanatory power of the variable is 0.671 or $67.1 \%$.This indicates that $67.1 \%$ of the variations in dividend are due to inadequate liquidity management. The remaining $32.9 \%$ of changes however, are explained by variables not considered in this work but can cause variation in the dependent variable Dividend.

At the level of significance of 0.05 and degree of freedom 53, the $t$-statistics is 10.303 which is greater than the tabulated of 1.676; while the $\mathrm{p}$-value of the $\mathrm{t}$-statistics is 0.000 which is less than 0.05 . We therefore reject the null hypothesis and accept the alternate which shows that inadequate liquidity management has a significant negative impact on the dividend payments of deposit money banks in Nigeria. The Cronbach alpha reliability rate is 0.75 which greater than the global standard of 0.70 (Tables 10 and 11). 
Citation: Adegbie FF, Dada OT (2018) Risk Assets Management, Liquidity Management and Sustainable Performance in Nigeria Deposit Money Banks. Int J Account Res 6: 178. doi: 10.35248/2472-114X.18.6.178

Page 9 of 10

\begin{tabular}{|c|c|c|c|c|}
\hline \multirow{2}{*}{ Model } & \multicolumn{2}{|c|}{ Unstandardized Coefficients } & Standardized Coefficients & Beta \\
\cline { 2 - 5 } & B & Std. Error & 0.819 & 3.295 \\
\hline $\begin{array}{c}\text { (Constant) } \\
\text { Inadequate liquid } \\
\text { management }\end{array}$ & 1.077 & 0.327 & 0.002 & 0.303 \\
\hline aDependent Variable: PAT@Banks. & 0.775 & 0.075 & 0 \\
\hline
\end{tabular}

Table 12: Coefficients ${ }^{\mathrm{a}}$.

\section{Implications of the findings}

The study has indicated to the operators of the deposit money banks that for sustainable performance to be maintained and avoid insolvency, effective risk assets and liquidity management need to be a strategy in the banking industry. It is a pointer to the regulatory authority that financial and liquidation can be avoided if the regulatory controls can further be strengthened. Proper documentation and computerization of banks returns are essentials for control achievement. The investors' confidence in the deposit money banks will be strengthened if shareholders and firm objectives are achieved through sustainable performance.

\section{Conclusion}

The results of the findings show that there is a significant relationship between risk asset, liquidity management and sustainable performance of deposit money banks in Nigeria. Non-performing loans have a significant negative impact on the assets of deposit money banks, low level of cash deposits has a significant negative impact on the total capital of the deposit money banks, there is a significant relationship between non-compliance with cash reserve requirement on cash balance and the profitability of deposit money banks in Nigeria and the study found that inadequate liquidity management has a significant negative impact on the dividend payment in deposit money banks in Nigeria. Even though profitability is the primary objective of every banking business, more attention is directed towards other performance measures in order to maintain sustainable performance. However, it only by adequate liquidity management can a bank minimize risk assets and liquidity risks, grow assets, maintain profit, pay dividends to the owners, and meet other stakeholders objectives.

\section{Recommendations}

Based on the findings of the study, the following recommendations are very imperative for the sustainability of the performance of the banking institutions in Nigeria.

All banks should comply with cash reserve requirements, which help them to avoid insolvency and maintain sustainability profitability. The regulatory authorities should ensure tight monitoring of the activities of the banks to avoid financial distress. This will also guarantee transparency in their financial reporting to the stakeholders in the banking industry.

All banks should institute sound risks asset and liquidity management system that will guarantee the earnings quality of their loans and advances, avoid non-performing loans and advances and enhance the quality of their earnings. This will have positive effect on dividends payments, funds retention and growth in capital and assets of the institutions.

\section{References}

1. Agbada AO, Osuji CC (2013) The Efficacy of Liquidity Management and Banking Performance in Nigeria. Int Rev Manage Bus Res, 2: 223-233.

2. Abang-Anoh charity A (2012) The impact of liquidity on the performance of commercial banks in Nigeria (unpublished MSc Project) submitted to Department of economics, faculty of management and social sciences ,caritas University, Amorji Nike, Emene, Enugu State.

3. CBN and NDIC (1995) Definition of Distress and Analytical Framework Distress in the Nigerian Financial Services Industry. Collaborative study. NDIC Publication.

4. Onoh JK (2002) Dynamics of Money, Banking and Finance in Nigeria-An Emerging Market. Aba. Astra Meridian Publishers.

5. CBN (2004) A Case Study of Distressed Banks in Nigeria-Research and Statistics Department. Abuja. Central Bank of Nigeria Publication.

6. Owojori AA, Akintoye IR, Adidu FA (2011) The Challenge of Risk Management in Nigerian Banks in the Post Consolidation Era. J Accounting and Taxation, 3: $23-31$.

7. Okechukwu ND, Chigozie CF (2012) Economic Reforms and Social Science delivery in Nigeria 1997-2007: issues and options. Arabian J Bus Manage Rev, 2: $9-23$.

8. Soludo CC (2004) Consolidating the Nigerian Banking Industry to Meet the Development Challenges of the $21^{\text {st }}$ Century. In being an address delivered to the Special Meeting of the Bankers Committee, V: 6.

9. Proshare Intelligent Investing (2017) Capital Market.

10. Kartik CN (2010) Trends in Liquidity Management And Their Impact On Profitability: A Case Study. Great Lakes Herald, 6:16-30.

11. Qasim Saleem and Ramiz Ur Rehman (2011) Impacts of liquidity ratios on profitability. Interdiscip j res bus, 1: $95-98$

12. Owolabi SA, Obida SS (2012) Liquidity Management and Corporate Profitability Case Study of Selected Manufacturing Companies Listed On the Nigerian Stock Exchange. Bus Manage Dyn, 2: 10-25.

13. Samuel OF (2011) Banking sector Liquidity and Financial Crisis in Nigeria. Int j Econ Finance, 3: 3-11.

14. Olagunju AA, Olanrewaju D, Olabode OS (2011) liquidity management and commercial banks profitability in Nigeria. Res j finance accounting, V: 2

15. Valla N, Saes-Escorbiac B, Tiesset M (2006) Bank liquidity and financial stability. Banque de france financial stability reviews, 9: 89-104.

16. Fadare SO (2011) Banking Sector Liquidity and Financial Crisis.

17. Ajibola (2018) The Structure of Nigeria's economy (1960-2017) (First edition) Lagos. The CIBN Presss Limited.

18. African Economic Outreach (2016) Nigeria Economic Outlook.

19. Asogwa R, Barungi B, Odhiambo O (2017) Nigeria

20. FSDH (2017) A Changing Economy: Economic and Financial Markets Outlook 2017-2021.

21. Basel Committee (2008) Banking Supervision.

22. Patricia CN, Izuchukwu CD (2014) The Relationship between Regulatory Inconsistencies and Nigerian Banking Industry. Global J Manage Bus Res, 14 45-72.

23. Regina GO (2012) Performance Evaluation of Nigerian Commercial Banks: Before and after Consolidation. IJERMR, V: 2

24. Njogo BO (2012) Risk Management in the Nigerian Banking Industry. Kuwait Chapter of Arabian J Bus Manage,V: 1.

25. Sunny OI (2013) The impact of liquidity management on the profitability of banks in Nigeria. J finance bank manage, 1: 37-48.

26. Ngwu TC (2006) Risk Management in Nigeria Banking Industry. 
Citation: Adegbie FF, Dada OT (2018) Risk Assets Management, Liquidity Management and Sustainable Performance in Nigeria Deposit Money Banks. Int J Account Res 6: 178. doi: 10.35248/2472-114X.18.6.178

27. Adegbie FF, Asaolu TO, Enyi EP (2013) Distress Resolution in Nigerian Banking Sector: The Role of Assets and Liabilities management. Int J Financial Res, 4: 70-82.

28. Somoye ROC (2010) The Variation of Risks On Non-Performing Loans on Banks Performance. Indian J Economic Bus 9.

29. Enyi EP (2013) Assets Accounting Affects Performance Reporting of Firms https://www.omicsline.org/editor downloaded May 23, 2018.

30. Ekankumo B, Koroye BH (2011) Sales Promotion Strategies of Financia Institutions in Bayelsa State. Asain J Bus Manage 3: 203-209.

31. Lawrence I (2015) Capital Base And Performance of Money Deposit Banks In Nigeria: Pre And Post Consolidation Era. Int J Managerial Stud Res, 3: 74-82.

32. Ibrahim EA (2014) The Impact of Liquidity on the Dividends Policy. Proceedings of $26^{\text {th }}$ International Business Research Conference 7-8, imperial College, London, UK.
33. Hashim Z, Shahid R, Sajid I, Umair A (2013) Determinants of Dividend Policy A Case Study of Banking Sector In Pakistan. Middle-East J Sci Res, 18: 410-424.

34. Douglas JE (2014) Bank Liquidity Requirements: An Introduction Overview. The Brookings Institution.

35. Unaeze NF (2012) "An Evaluation Of The Impact Of Supervision And Contro of The Central Bank on The Performance of Commercial Banks" (Unpublished Msc Project) Submitted to Department of Business Administration, Faculty of Management And Social Sciences, Caritas University, Amorji Nike, Emene, Enugu State.

36. CBN (2012) Central Bank of Nigeria Annual Reports

37. Lawal BD (2012) Impact of Government Withdrawal of Deposits from Commercial Banks in Nigeria. Int J Acad Res Econ Managerial Sci V: 1.

38. NDIC (2010) Central Bank New Prudential Guidelines.

39. PWC (2017) Prudential Guidelines Differences between SAS10 and the Revised Prudential Guidelines. 